\title{
Survey of Major Viruses in Commercial Nursery Trees of Major Pear Cultivars in Korea
}

*Corresponding author

Tel: $+82-62-530-2075$

Fax: $+82-62-530-2069$

E-mail:jraed2@jnu.ac.kr

Received November 20, 2018

Revised January 15, 2019

Accepted January 15, 2019

\author{
Nam-Yeon Kim ${ }^{1}$, Hyo-Jeong Lee', Na-Kyeong Kim ${ }^{1}$, Jonghee $\mathrm{Oh}^{2}$, Su-Heon Lee ${ }^{2}$, \\ Hongsup Kim³ ${ }^{3}$ Jae Sun Moon ${ }^{4}$, and Rae-Dong Jeong ${ }^{1 *}$ \\ ${ }^{1}$ Department of Applied Biology, Institute of Environmentally Friendly Agriculture, Chonnam National \\ University, Gwangju 61185, Korea \\ ${ }^{2}$ School of Applied Biosciences, Kyungpook National University, Daegu 98411, Korea \\ ${ }^{3}$ Seed Testing \& Research Center, Korea Seed \& Variety Service, Gimcheon 39660, Korea \\ ${ }^{4}$ Plant Genome Research Center, Korea Research Institute of Bioscience \& Biotechnology, Daejeon \\ 34141, Korea
}

\begin{abstract}
Apple chlorotic leaf spot virus (ACLSV), Apple stem pitting virus (ASPV), Apple stem grooving virus (ASGV), and Apple scar skin viroid (ASSVd) are economically important viruses that infect pear tree species worldwide. To evaluate the prevalence of these viruses in Korea, we investigated infection degree of three viruses and one viroid for the commercial nursery trees of the pear cultivars, Niitaka, Chuwhang, Wonwhang, and Whasan in 2017 and 2018. The results showed that the infection ratio of ACLSV, ASPV, ASGV, and ASSVd for the scion of pear cultivar Niitaka was 10\%, 45\%, 77\%, and 50\%, respectively. From the scion of pear cultivar Chuwhang, infection ratios of ASPV, ASGV, and ASSVd were found to be $70 \%, 50 \%$, and $60 \%$, respectively. From the scion of pear cultivar Whasan, infection ratios of ACLSV, ASPV, ASGV and ASSVd were found to be $40 \%, 60 \%, 93 \%$, and $20 \%$, respectively. From the root stock of pear cultivar Wonwhang, infection ratios of ACLSV, ASPV, ASGV, and ASSVd showed 28\%,57\%, 100\%, and 14\%, respectively. ASGV had the highest recorded infection rate, and ACLSV was characterized by the lowest infection rate. The mixed infection ratio of Niitaka, Chuwhang, Whasan, and Wonwhang was $45 \%, 60 \%, 70 \%$, and $85 \%$, respectively.
\end{abstract}

Keywords: ACLSV, ASGV, ASPV, ASSVd, commercial pear tree nursery
Viruses and virus-like diseases act as a roadblock to the sustainable production of high-quality pears. Infections with single viruses, and mixed infections with multiple viruses, which are common in pear, cause economic losses to pear industries worldwide (Németh, 1986; Schmidt, 1972). Asian pear (Pyrus pyrifolia), which is one of six major fruits in Korea, has been cultivated worldwide for consumption of fresh fruits. Pome fruit trees can be infected by several viruses and

Research in Plant Disease

pISSN 1598-2262, elSSN 2233-9191

www.online-rpd.org virus-like pathogens, including Apple chlorotic leaf spot virus (ACLSV), Apple stem pitting virus (ASPV), Apple stem grooving virus (ASGV), Apple mosaic virus (ApMV), and Apple scar skin viroid (ASSVd) (Mahfoudhi et al., 2013; Pūpola et al., 2011). Three viruses (ACLSV, ASPV, and ASGV) have been reported to occur in pear trees in Korea (Cho et al., 2010). Starting in 2000 , the industry has experienced several outbreaks of viral diseases across the country. Infected pear trees showed severe symptoms, including yellowing vein, deformation, black necrotic leaf spots, chlorotic leaf spots, and mosaic patterns on leaves. Examining the type of viruses, their prevalence, and the severity of viral disease is a critical first step for the 
Table 1. Primer sequences and expected size for detection of pear viruses and viroid by multiplex RT-PCR

\begin{tabular}{|c|c|c|c|}
\hline Target & Primer sequence (5'-3') & Product size (bp) & Reference \\
\hline Apple chlorotic leaf spot virus & GCAGACCCCTTCATGGAAGA & 509 & Bae, 2015 \\
\hline$(\mathrm{ACLSV})$ & CGCAAAGATCAGTCGTAACAGA & & \\
\hline$(\mathrm{ASPV})$ & GATCAACTITACTAAAAAGCATAAGT & & \\
\hline Apple stem grooving virus & GCCACTTCTAGGCAGAACTCTITGAA & 273 & Menzel et al., 2002 \\
\hline$($ ASSVd $)$ & CCGCTGCGTCAAAGAAAAAG & & \\
\hline Apple mosaic virus & CTCCAAACACAACTITTGATGACTT & 123 & Bae, 2015 \\
\hline (ApMV) & GTAACTCACTCGTTATCACGTACAA & & \\
\hline
\end{tabular}

control of pear viruses. To control pome fruit viruses, ensuring virus-free propagated materials is important because infected plants present a major risk of transmitting infection through grafting. However, viral diseases in commercial pear nursery trees have not been studied in recent years. To obtain a comprehensive picture of viral infection of pear trees in the market, we conducted a survey of viral infections in commercial pear nurseries in four different locations in 2017 and 2018.

To investigate the status of viral infections in commercial pear nursery trees, we purchased 72 pear nursery trees (one or two years old) during the spring season in four different locations (Daegu, Okcheon, Seongnam, and Wanjoo) in 2017 and 2018. An immuno-tissue printing assay revealed that ACLSV and ASGV were found mainly epidermis in apple shoots (Knapp et al., 1995). Epidermal tissues taken from the scions of tree samples from four pear cultivars (Niitaka, Chuwhang, Whasan, and Wonhwnag) were ground in liquid nitrogen and stored at $-80^{\circ} \mathrm{C}$ until RNA could be extracted for virus detection. Total RNA was extracted from ground samples using the IQeasy plus plant RNA extraction Mini Kit (iNtRON, Daejeon, Korea) according to the manufacturer's recommendations. For rapid detection of the viruses and viroid, multiplex RT-PCR was performed using SuPrimeScript RT-PCR Premixture (GeNet Bio, Daejeon, Korea). Two microliters of total RNA, forward primers, and reverse primers for four viruses and one viroid [ACLSV, ASPV, ApMV, and ASSVd (10 pmol), ASGV ( 2 pmol)] were added to the RT-PCR premix and filled with DEPC water to $20 \mu \mathrm{l}$ (Bae, 2015; Men- zel et al., 2002) (Table 1). RT-PCR was conducted as follows: stage $1: 50^{\circ} \mathrm{C}$ for $30 \mathrm{~min}$; stage $2: 95^{\circ} \mathrm{C}$ for $5 \mathrm{~min}$; stage $3: 38$ cycles of $95^{\circ} \mathrm{C}$ for $30 \mathrm{~s}, 58^{\circ} \mathrm{C}$ for $30 \mathrm{~s}$ and $72^{\circ} \mathrm{C}$ for $60 \mathrm{~s}$; and stage $4: 72^{\circ} \mathrm{C}$ for $5 \mathrm{~min}$. The sizes of the PCR products were confirmed with $2 \%$ agarose gel electrophoresis. To confirm the identity of the viruses and viroid in the pear trees, some of the positive samples were purified using the MEGAquickspin $^{\text {TM }}$ plus fragment DNA purification kit (iNtRON, Korea) and determined after cloning into a pGEM- T Easy Vector System (Promega, USA); nucleotide (nt) sequence analysis was carried out by Bionics (Daejeon, Korea). The nt sequences were edited using the EditSeq program in the Lasergene software (DNASTAR, USA) and analyzed by NCBI BLAST analysis.

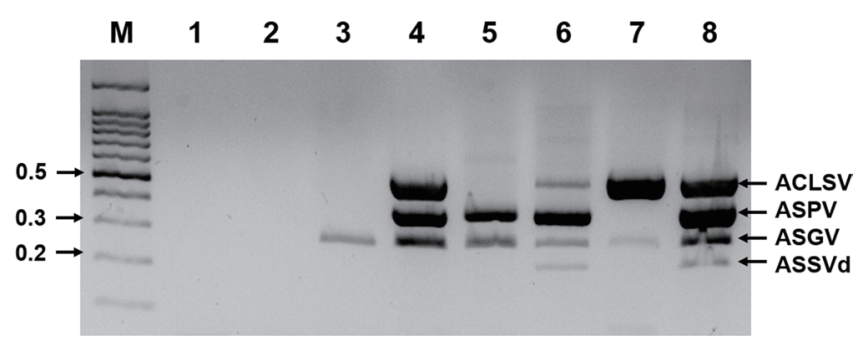

Fig. 1. Agarose gel electrophoretic analysis of one-tube multiplex RT-PCR products amplified from total RNA preparations of virusinfected pear nursery tree tissues. RT-PCR products amplified from samples non-infected pear leaf (line 1); and water control (line 2); infected with different pome fruit viruses and viroid (lines 3-8). The bands corresponding to each virus have the following lengths: 202 bp for Apple scar skin viroid; 273 bp for Apple stem grooving virus; 367 bp for Apple stem pitting virus; 509 bp for Apple chlorotic leaf spot virus. 
Table 2. The incidence of viral infection in pear nursery trees according to different locations and pear cultivars

\begin{tabular}{|c|c|c|c|c|c|c|c|}
\hline \multirow{2}{*}{ Location } & \multirow{2}{*}{ Cultivar } & \multicolumn{2}{|c|}{ Samples } & \multicolumn{4}{|c|}{ Detected } \\
\hline & & Tested & Infected & ACLSV & ASPV & ASGV & ASSVd \\
\hline \multirow[t]{2}{*}{ Daegu } & Niitaka & 5 & 5 & - & 3 & 4 & 4 \\
\hline & Chuwhang & 10 & 9 & - & 7 & 5 & 6 \\
\hline \multirow[t]{2}{*}{ Okcheon } & Niitaka & 10 & 10 & - & 2 & 10 & 5 \\
\hline & Whasan & 5 & 5 & 2 & 2 & 4 & 2 \\
\hline Seongnam & Niitaka & 20 & 17 & 1 & 9 & 12 & 10 \\
\hline \multirow[t]{3}{*}{ Wanjoo } & Niitaka & 5 & 5 & 3 & 4 & 5 & 1 \\
\hline & Whasan & 10 & 10 & 4 & 7 & 10 & 1 \\
\hline & Wonhwang & 7 & 7 & 2 & 4 & 7 & 1 \\
\hline Total & & 72 & 68 & 12 & 38 & 57 & 30 \\
\hline fection rate (\% & & & 94.4 & 16.7 & 52.8 & 79.2 & 41.7 \\
\hline
\end{tabular}

Virus infection was analyzed by multiplex RT-PCR.

Values are presented as number only or number (virus infection rates [\%]).

ACLSV, Apple chlorotic leaf spot virus; ASPV, Apple stem pitting virus; ASGV, Apple stem grooving virus; ASSVd, Apple scar skin virioid; -, no virus detected.

All 72 pear nursery tree samples were tested using the multiplex RT-PCR (Fig. 1, Table S1). Of the 72 pear nursery samples, 68 samples were positive for at least one virus or viroid (94.4\%) while ApMV was not detected (Table 2). Among all studied pear cultivars, the highest infection rate was reported for ASGV (79.2\%), followed by ASPV (52.8\%). The distribution of ACLSV (16.7\%) was minor, and ApMV did not show any positive reaction in the pear nursery samples. In samples collected from Daegu, ASPV (66.7\%), ASGV (60.0\%), and ASSVd (66.7\%) were detected in all cultivars, but ACLSV was not detected in Niitaka and Chuwhang cultivars. Unlike the samples collected from Daegu, the samples collected from Okcheon, were from the Niitaka and Whasan cultivars, and ACLSV (13.3\%), ASPV (26.7\%), ASGV (93.3\%), and ASSVd (46.7\%) were detected in these samples. In samples collected from Seongnam, ACLSV (5.0\%), ASPV (45.0\%), ASGV (60.0\%), and ASSVd $(50.0 \%)$ were detected in Niitaka cultivar. In Wanjoo, all three viruses and one viroid were detected at the following rates: ACLSV (40.9\%), ASPV (68.2\%), ASGV (100\%), and ASSVd (13.6\%). ASGV was detected in four cultivars: Niitaka (77.5\%), Chuwhang (50.0\%), Whasan (93.3\%), and Wonhwang (100\%). In addition, ASGV was detected at the highest frequency as compared to others. Among them, ASPV and ASSVd were detected in all tested pear cultivars while ACLSV was detected in only three cultivars: Niitaka (10.0\%), Whasan (40.0\%), and Wonhwang (28.6\%). The results showed that viral diseases were characterized by spreading that differs among pear cultivars. Data for single and mixed infections (two to four viruses and/or viroids) are listed in Table 3. Analysis of the single infection pattern confirmed that the most recurrent virus found in single infection was ASGV (19.4\%) with 14 samples, followed by ASSVd (8.3\%) and ASPV (2.8\%), respectively. Though the number of viruses detected varied among the pear cultivars, overall, all major cultivars were heavily infected with multiple viruses. Most collected samples were infected by two or three different viruses and the viroid. There were nine different combinations of mixed virus infections: 26 samples were doubly infected, 17 samples were triply infected, and 3 samples were quadruply infected. Double infection of ASPV and ASGV had the highest recorded incidence (approximately 20.8\%), followed by triple infection of ASPV, ASGV, and ASSVd (13.9\%), and double infection of ASGV and ASSVd (9.7\%). Other combinations of mixed viral infection rates were as follows: double infection of ACLSV and ASGV (2.8\%), ASPV and ASSVd (2.8\%), triple infection of ACLSV, ASPV, and ASGV (6.9\%), ACLSV, ASPV, and ASSVd (1.4\%), ACLSV, ASGV, and ASSVd (1.4\%), and quadruple infection of ACSLV, ASPV, ASGV, and ASSVd (4.2\%). The 
Table 3. Single and mixed viral infection rates (\%) in pear nursery trees according to different locations and pear cultivars

\begin{tabular}{|c|c|c|c|c|c|c|c|c|c|}
\hline & \multicolumn{2}{|c|}{ Daegu } & \multicolumn{2}{|c|}{ Okcheon } & \multirow{2}{*}{$\begin{array}{c}\text { Seongnam } \\
\text { Niitaka }\end{array}$} & \multicolumn{3}{|c|}{ Wanju } & \multirow{2}{*}{$\begin{array}{c}\text { Infection } \\
\text { rate (\%) }\end{array}$} \\
\hline & Niitaka & Chuwhang & Niitaka & Whasan & & Niitaka & Whasan & Wonhwang & \\
\hline \multicolumn{10}{|l|}{ Single infection } \\
\hline ASGV & & & 4 & 3 & 3 & & 3 & 1 & $14 / 72^{*}(19.4)$ \\
\hline ASPV & & 2 & & & & & & & 2/72 (2.8) \\
\hline ASSVd & 1 & & & & 5 & & & & 6/72 (8.3) \\
\hline \multicolumn{10}{|l|}{ Mixed infection } \\
\hline ACLSV+ASGV & & & & & & 1 & & 1 & 2/72 (2.8) \\
\hline ASPV+ASGV & 1 & 1 & 1 & & 3 & 2 & 3 & 4 & $15 / 72(20.8)$ \\
\hline ASGV+ASSVd & 1 & 2 & 4 & & & & & & 7/72 (9.7) \\
\hline ASPV+ASSVd & & 2 & & & & & & & $2 / 72(2.8)$ \\
\hline$A S P V+A S G V+A S S V d$ & 2 & 2 & 1 & & 5 & & & & 10/72 (13.9) \\
\hline$A C L S V+A S P V+A S S V d$ & & & & 1 & & & & & $1 / 72(1.4)$ \\
\hline $\mathrm{ACLSV}+\mathrm{ASPV}+\mathrm{ASGV}$ & & & & & 1 & 1 & 3 & & $5 / 72(6.9)$ \\
\hline$A C L S V+A S G V+A S S V d$ & & & & & & & & 1 & $1 / 72(1.4)$ \\
\hline $\begin{array}{c}\text { ACLSV+ASPV+ } \\
\text { ASGV+ASSVd }\end{array}$ & & & & 1 & & 1 & 1 & & $3 / 72(4.2)$ \\
\hline
\end{tabular}

Virus infection was analyzed by multiplex RT-PCR

Values are presented as number only or number (virus infection rates [\%]).

*Number of samples infected/number of samples collected.

ACLSV, Apple chlorotic leaf spot virus; ASPV, Apple stem pitting virus; ASGV, Apple stem grooving virus; ASSVd, Apple scar skin virioid; -, no virus detected.

RT-PCR products of the coat protein (CP) gene of viruses or complete viroid genome were confirmed by sequence analysis using BLAST tools. An NCBI BLAST analysis showed that each virus had high nt identity with previously reported isolates. The ACLSV isolate (LC455709) showed the highest nt identity (98\%) with the KP1 isolate (LC367336) reported in Korea. The ASPV isolate (LC455710) shared nt identity (93\%) with the PA66 isolate (D21829) reported in pear in Germany. ASGV (LC455711) shared the highest nt identity (97\%) with N297 isolate (LC184610) from Cirus unshiu in Japan. The ASSVd isolate (LC455712) showed the highest nt identity (100\%) with the GH2 isolate (LC431517), reported in apples in Korea. A previous study reported the incidence of three viruses (ACLSV, ASPV, and ASGV) in three cultivars of pear trees from different locations and found that ASGV was the most prevalent (Cho et al., 2010). Here, we report on the results of a survey for three viruses and a viroid in commercial pear nursery trees in Korea. Our results showed that three viruses and one viroid were detected in commercial pear nursery trees in different locations of Korea. Moreover, mixed infection of the three viruses and one viroid (ACLSV, ASPV, ASGV, and ASSVd) is a new finding in commercial pear nursery trees. It is unknown why these pear trees were heavily infected with multiple viruses. Undoubtedly, one of the main reasons could be the use of uncertified, virus-infected planting materials. It is important to continue investigation on commercial pear trees to monitor the phytosanitary status with regards to transmissible infections through the propagating material. All the viruses and viroid detected during this survey should be taken into consideration when a national certification program runs for the production of virus-free pear trees so that marketing of sanitarily improved pear fruit propagative material will be updated, as it seems highly desirable. These survey results demonstrate the infection rate of the major viruses in pear nursery trees and underline the importance of a nationwide clean stock certification program in Korea. 


\section{Conflicts of Interest}

No potential conflict of interest relevant to this article was reported.

\section{Acknowledgments}

This work was supported by Korea institute of Planning and Evaluation for Technology in Food, Agriculture, Forestry and Fisheries (IPET) through (Agri-Bioindustry Technology Development Program), funded by Ministry of Agriculture, Food and Rural Affairs (MAFRA) (No. 317006-04-2-HD030).

\section{References}

Bae, Y. S. 2015. Development of multiplex RT-PCR for apple viruses and viroid and the incidence of apple viral disease in Gyeongsangbuk-do. Master's thesis. Kyungpook National University, Daegu, Korea.

Cho, I. S., Kim, D. H., Kim, H. R., Chung, B. N., Cho, J. D. and Choi, G. S. 2010. Occurrence of pome fruit viruses on pear trees (Pyrus pyrifolia) in Korea. Res. Plant Dis. 16: 326-330 (in Korean).

Knapp, E., da Câmara Machado, A., Pühringer, H., Wang, Q., Hanzer, V., Weiss, H. et al. 1995. Localization of fruit tree viruses by immune-tissue printing in infected shoots of Malus sp. and Prunus sp.. J. Virol. Methods 55: 157-173.

Mahfoudhi, N., El Air, M., Salleh, W., Moujahed, R. and Djelouah, K. 2013. Occurrence and distribution of pome fruit viruses in Tunisia. Phytopathol. Mediterr. 52: 136-140.

Menzel, W., Jelkmann, W. and Maiss, E. 2002. Detection of four apple viruses by multiplex RT-PCR assays with coamplification of plant mRNA as internal control. J. Virol. Methods 99: 81-92.

Németh, M. 1986. Viruses, mycoplasma and rickettsia diseases of fruit trees. Springer Netherlands, Dordrecht, The Netherlands. 750 pp.

Pūpola, N., Moročko-Bičevska, I., Kāle, A. and Zeltinš̌, A. 2011. Occurrence and diversity of pome fruit viruses in apple and pear orchards in Latvia. J. Phytopathol. 159: 597-605.

Schmidt, H. 1972. The effect of latent virus infections on the yield of maiden trees on 20 apomictic apple seedling rootstocks. J. Hortic. Sci. 47: 159-163. 